Guido Wilke und Jürgen Ortmeier

\title{
Coatings for Plastics
}


Cover: Karl Wörwag Lack- und Farbenfabrik GmbH \& Co. KG

Bibliographische Information der Deutschen Bibliothek Die Deutsche Bibliothek verzeichnet diese Publikation in der Deutschen Nationalbibliographie; detaillierte bibliographische Daten sind im Internet über http://dnb.ddb.de abrufbar.

\section{Guido Wilke and Jürgen Ortmeier}

Coatings for Plastics

Hanover: Vincentz Network, 2012

European Coatings Tech Files

ISBN 978-3-7486-0222-4

\section{(C) 2012 Vincentz Network GmbH \& Co. KG, Hanover}

Vincentz Network, Plathnerstr. 4c, 30175 Hanover, Germany

This work is copyrighted, including the individual contributions and figures

Any usage outside the strict limits of copyright law without the consent of the publisher is prohibited and punishable by law. This especially pertains to reproduction, translation, microfilming and the storage and processing in electronic systems.

The information on formulations is based on testing performed to the best of our knowledge.

The appearance of commercial names, product designations and trade names in this book should not be taken as an indication that these can be used at will by anybody. They are often registered names which can only be used under certain conditions.

Please ask for our book catalogue

Vincentz Network, Plathnerstr. 4c, 30175 Hanover, Germany

T +495119910-033, F +495119910-029

books@european-coatings.com,www.european-coatings.com

Layout: Danielsen Mediendesign, Hanover, Germany 


\section{Another interesting book hint...}

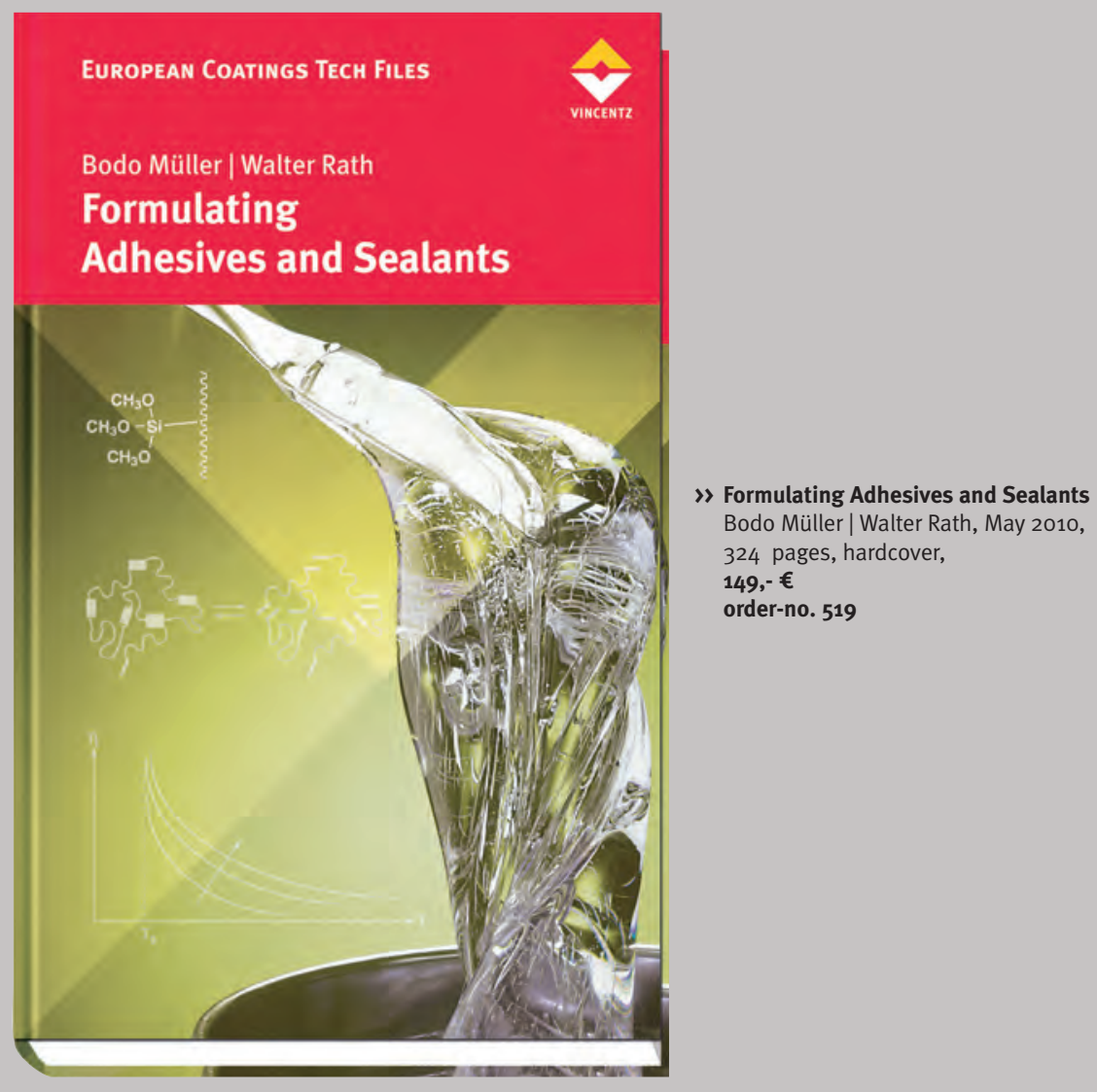

\section{Formulating Adhesives and Sealants}

Each section describes the application and chemical basis of the type of adhesive or sealant. It is followed by formulation advice and an analysis of existing recipes. This analysis includes a calculation of the important characteristic values of the formulations.

Order at: www.european-coatings.com/shop 

European Coatings Tech Files

Guido Wilke und Jürgen Ortmeier

\section{Coatings for Plastics}




\section{SCHLENK 】}
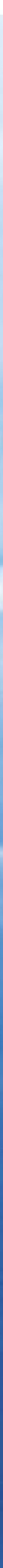

Now available

for iPad

in the App Store

Schlenk is one of the leading manufacturers of effect pigments worldwide, with production sites and technical service centers in Europe, USA and China. A full range of metallic pigments for the coating, printing ink and plastic industries as well as press ready inks are manufactured to specific customer requirements to assure excellent performance.

Environmentally-friendly pigment systems for powder, waterbase and UV technologies distinguish themselves through their unique effects.

State-of-the-art development, together with worldwide technical application support, place our customers in a "POWERFULL POSITION". 